\title{
'Folk Ideas' and 'Worldview' Inscribed in a Selection of Folktales Attributed to the Muslim Community of the East Coast of Sri Lanka
}

\section{Lal Medawattegedara*}

Department of Language Studies, Faculty of Humanities and Social Sciences, The Open University of Sri Lanka, Nawala, Sri Lanka

\begin{abstract}
Seeming absence of focused scholarly intervention has not deterred folklorists from considering, orally transmitted imaginative speech acts-such as folktales-as a specific community's "autobiographical ethnography" (Dundes, 2007) or their "own descriptions of themselves" (Dundes, 2007). In Sri Lanka, (Sinhala) folktales are an essential feature in school texts books, children's newspapers, mass media, and Sinhala folktale collections are frequently released for public consumption with some prominent bookshops offering exclusive shelf space for this genre. A collection of Sri Lankan folktales attributed to a specific geography and an ethnic community is the focus of this study. The collection is titled Digamadulle Muslim Janakatha and its collector/compiler is Gunasekera Gunasoma, a popular folktale collector in Sri Lanka, and a fiction writer. Gunasoma offers 16 folktales collected from Digamadulle in this book and his endeavor could possibly be the first such collection of folktales attributed to the Muslim ethnic community living in Digamadulle, or for that matter anywhere else in Sri Lanka. The present study attempts to extract the cultural postulates featured in these tales, theoretically identified as 'folk ideas' and 'worldview' by folklorists. Using definitions of the folklorist Allan Dundes, this study undertakes a close reading of the folktale sample under consideration to comprehend how the Muslim story tellers/creators/listeners of
\end{abstract}

\footnotetext{
* Correspondence should be addressed to Lal Medawattegedara.

Email: lalmedawattegedara@gmail.com
}

iD https:/ / orcid.org/0000-0003-3351-1889

(Received 19th September 2017; Revised 07th October 2017; Accepted 24th October 2017) (C) OUSL 
Digamadulle perceived and imagined the 'world' and its nature. Scholar Samarsinghe's (2014) view that folktales facilitate 'social cohesion' would also play into the motivations of this study, whose primary objective is cultural comprehension.

Key words: Folk Ideas, Worldview, Cultural Postulates, Social Cohesion

\section{Introduction}

Folklorists commonly agree that traditional ideas shared by a group of people living in a specific socio-cultural context tend to underpin their imaginative speech acts such as folk songs, folk proverbs, folk games and folktales. A folktale, the focus of this study, is a "traditional narrative" (Samarasinghe, 2014) in speech or writing that offers "advice, entertainment, amusement and warning" (Samarasinghe, 2014). Presently, there is a resurgence of public interest in folktales, specifically in southern Sri Lanka, as apparent from the large number of folktale collections-both local and global - that are released for public consumption ${ }^{1}$. The present study focuses on a collection of folktales attributed to the followers of the Islam faith in Sri Lanka, identified as 'Muslim,' living in a specific geographical space, Digamadulle in the Eastern Province. The collection is titled Digamadulle Muslim Janakatha (Folktales from Digamadulla) and the collector/compiler is Gunesekera Gunasoma, a prominent folktale collector in Sri Lanka. This study attempts to engage this collection of tales in a close reading to extract cultural axioms, which are identified as 'folk ideas' by folklorists. According to Dundes (2007), 'folk ideas' are "traditional notions that a group of people have about the nature of humanity, of the world, and of life in the world" (Dundes, 2007). Rather than being a living genre of folklore (like folk songs or folk proverbs), Dundes (2007) further argues that, 'folk ideas' underlie the thoughts and actions of a group of people. Many individual 'folk ideas,' Dundes suggests, are the "building blocks of worldview" (Dundes, 2007), and he defines 'worldview' as "cognitive, existential aspects of the way the world is structured" (Dundes2007). These definitions, one could argue, are helpful as

${ }^{11}$ Majority of these folktale collections are tales from the Sinhala ethnic community, and are written in Sinhala; there are few collections attributed to the South Indian Tamil ethnic community-the most notable ones being those translated by Sunil Ariyaratne, 
well as problematic. The terms 'nature of humanity' and 'life in the world' might not be expedient when it comes to sieving specific ideas from the general; a term like 'cognitive' could be complex when it comes to interpretation. Yet, the open-ended nature of these definitions aids the present study: rather than imposing distilled theoretical models upon the tales told/created/heard by rural folk, the definitions permit flexibility of interpretation, and facilitate the inclusion of more beliefs and value systems in the present discussion.

Story telling/creating/hearing is not a neutral act. Orally transmitted speech acts tend to reproduce, according to Bronner (2005), "biases, prejudices, belief and values through time and space," and this process happens often "unconsciously or unselfconsciously" (Dundes, 2007). Both these scholars, and others specializing in folkloric gender studies (J.M. Taggart, Fumihiko Kobayashi and Vera Mark), agree on gender dichotomies as one of the frequently disseminated biases in folklore. Folktales are textual locations for unearthing lost historical narratives for the historian John Man and the anthropologist Gananath Obeysekere. While Man turns to folklore whenever he runs out of traditional textual sources in his attempt to narrate the history of the Genghis Khan's empire ${ }^{2}$, Obeysekere uses folktales collected from the region of Sigiriya villages to build an alternative account of the last days of the patricidal King Kassapa ${ }^{3}$. For Sri Lanka's foremost $20^{\text {th }}$ century Sinhala novelist, Martin Wickramasinghe folktales are "born out of people's real-life experience" (Wickramasinghe, 1948) a suggestion reflected in Dundes's argument that folklore is "autobiographical ethnography...people's own description of themselves" (Dundes, 2007). The present study attempts to add to the existing folklore scholarship in Sri Lanka by locating and interpreting cultural postulates inscribed in tales disseminated among a specific ethnic community of the nation. This writer is of the view that such imperatives might facilitate deeper reflective understandings of the Muslim ethnic community in Sri Lanka. The writer's view is further enhanced by Dundes's (2007) postulate that a careful identification of 'folk ideas' and 'worldview' in folktales could lead to better understanding between

${ }^{2}$ See Genghis Khan-Life, Death and Resurrection by John Man, Bantam Books: London,

${ }^{3}$ Quoted from History Writing: New Trends and Methodologies by Nira Wickramasinghe. See References for the full citation. 
cultures and peoples by reducing the "misunderstanding" (Dundes, 2007) that could result when different cultures come into contact with each other.

This study will first offer a short commentary on how the 'Muslims' are represented in the folkloric imagination of a sample of Sinhala folktales. This will be followed by a close reading of the folktale sample under focus leading on to the findings and conclusions. The term 'Muslim' is largely used in this study to refer to the story tellers in Gunasoma's collection, and wherever applicable, to the characters bearing that ethnic identity in the tales themselves.

\section{Representation of 'Muslims' in a sample of southern folktales}

Males from the Muslim ${ }^{4}$ community are featured in one of Sri Lanka's largest and the first folktale collections compiled by the British colonial irrigation officer Henry Parker. His 266 folktales, collected from the south and published in the early 20 st centurywhen exoticizing of the colonies by British writers was frequentfeature Muslim characters identified as 'moorman ${ }^{5}$,' 'Muhammadan trader,' thambi elder brother (Parker's translation Thambiaiyaa), 'Tambi,' or 'Arab traders.' Muslim males-not females! -are drawn into few of these tales by the story tellers/creators primarily as traders who journey into southern villages with their consumer goods. Yet, the representation of these fictitious characters falls into the realm of negativity: they are dim-witted, credulous-in one story, physically repulsive, and in another, a Muslim man is represented as reproducing in excess (a common stereotype attributed the Muslims in Sri Lanka even at present). Though only few tales feature the Muslims in Parker's collection, and this sample is not adequate to come to far-reaching and focused conclusions about the way the 'Muslim male' could have been perceived by the Sinhala story teller/creator and listeners, the existing evidence is suffice to say that they do not

${ }^{4}$ According to Siriweera (Facetsof 50) the Arabs were in contact with Sri Lanka even prior to the advent of Islam as part of their trading assignments. The Muslim traders established settlements here from the tenth and eleventh centuries onwards

5The 'Moor' identity, according to Nuhman (04), was imposed upon the Muslims by the colonial rulers-first by the Portuguese, then by the Dutch, though the term gained currency during British rule. 
necessarily find positive representations in the imaginative spaces of the Sinhalese. In this context observations recorded by two colonial writers might be interesting. John Davy, a British writer describes 'moormen' as "active, shrewd, enterprising race" (Davy, 1821); and the Portuguese writer De Bussche, while citing the Sinhalese as "not the most industrious part of the population" (De Bussche, 1817), presents the moormen as "by far [the] most industrious class of natives" (De Bussche1817).As questionable as the colonial textual enterprises on the colonized Lanka might have been, these descriptions signal the notion that the moormen could have been adept at winning the confidence of the colonial rulersand therefore, access to wealth creation-which might not have been appreciated by the Sinhala story tellers/creators/listeners, particularly in the light of their own resistance against the colonizers. With the fictitious moormen in the Sinhala imagination at its backdrop, this study will now analyze the possible means and modes by which the moormen might have understood the 'world' around him/her through their own folktales.

\section{Digamadulle Muslim Janakatha - a critical evaluation}

Gunasoma's folktale collection features 16 tales that he had collected from Digamadulle. He is quick to identify the numerical poverty of his slim collection-the reason being the difficulty in locating Muslim folktale narrators. His tales were collected from the villages of Kalmunai, Waripathchena, Akkaraipattu and Nindavur, with Akkaraipattu giving him the most number of tales. The time period of collection is the early eighties. Of the 17 story tellers, two are female, and the rest males, majority of the narrators are over the age of 50 years. Gunasoma, in the spirit of scientific tale collection, has electronically recorded the folktales directly from the narrators. He has faithfully noted down the basic biographical details of the narrators (name, address, gender, age) and the place of recording of the tale. However, there are certain lacks in Gunasoma's mode of tale collection. For instance, rather than recording a natural story-telling event in the presence of an active audience, Gunasoma has recorded the stories direct from the story teller. As a result, the important details of an act of storytelling, such as physical gestures and vocal modulations of the teller, the gender of the audience and their response to different aspects of a tale are not recorded. Most importantly, Gunasoma does not identify the language in which the stories were narrated-since the Muslims of Sri Lanka tend to be fluent 
in both Sinhala and Tamil, it is possible that they might have narrated the tales in either one of the languages; or a story teller might have resorted to mixing of the languages (code mixing) for better articulation of a plot event. Gunasoma does not offer us any such useful information. Yet, methodological deficiencies of tale collection in Sri Lanka is not a condition that only afflicts Gunasoma-he happens to be the most prolific folktale collector in the country, with over 300 tales to his credit, the other two prolific collectors being S. Wijesuriya (331 tales) and Henry Parker (266 tales). Neither Parker nor Wijesuriyahave pursued comprehensive scientific methods of tale collection either. Yet, despite these short comings, Gunasoma has offered the reading public of Sri Lanka a hitherto untried endeavor of visiting far-flung villages occupied by the Muslims, locating tale tellers, recording and publishing them. His is (possibly) the only collection of folktales attributed to the Muslims (of a specific geographic location) in Sri Lanka.

\section{Results and Discussion}

For ease of discussion and understanding, the 'folk ideas' inscribed in the tales are located, identified and presented as subheadings.

\section{Sanctity of a 'grave'}

The 'grave' (sohona) is a recurring motif in these tales and is imputed with the notion of sacredness, which inevitably grants the 'grave' power over human affairs. Thus, in the tale Kandulu Mala (The Weeping Flower), the grave of a young male who was unfairly killed by his own family gives birth to a flower of hypnotic beauty which resists attempts by many people to possess it. Subsequently, this flower narrates, in verse, the injustices committed to the deceased male, or the owner of the grave. ${ }^{6}$ In Yakada Yakka (The Metal Devil), a train undertaking its maiden journey along a newly-built track comes to a halt at a specific location and all attempts to rectify the issue end in failure ${ }^{7}$. The

6The Sinhala folktale The White Turtle in Henry Parker's Village Folk Tales of Ceylon Vol I features a similar motif, suggesting that the notion of the 'restless dead' who seek justice for their unfair death is commonly shared among both the Sinhala and Muslim communities.

${ }^{7}$ Popular folklore has it that the prominent Buddhist monk Kondadeniye Hamuduruwotoo caused a train to stop using magical incantations. This 
train was part of the ambitious transport initiatives of the (British) colonials, or the 'suddho', in Ceylon. Unwittingly, the rail track had been constructed over the grave (Siyaram) of a sacred man (avuliyavarayek). ${ }^{8}$ The village elders advice the authorities to ensure that the rail track circumvent the sacred grave; the authorities have no choice but to heed this advice. The tale Varipathchena is a creation myth about the village identified in the story title. The central attraction of this village is a sacred Siyaram which emanates bright light. All these tales offer the suggestion that the 'grave' of a pious man, and that of one who was unjustly dispatched to the other world, possesses super natural power and energy. The 'grave' of a pious person is sacred and demands respect; and the one belonging to an ordinary man who was unfairly killed demands justice. Such graves have the ability to manipulate the laws of physics and even disrupt the power dynamics between the colonizer and the colonized (a 'grave' undermines the forward path of a train). The underpinning 'folk idea' in these tales is that graves are sites that demand respect and reverence. Of course, one needs to read the tales metaphorically - they do not capture a 'literal truth,' but a 'projected state of affairs'; this 'projected state of affairs might be a response to a condition in 'reality' that might not be to the liking of a story creator/teller/listener. Thus, the motif of the 'grave' of a sacred man valorizes a specific 'mode of living'-one based on the tenants of Islam. The virtuous adherents of Islam are 'alive' even though they are 'dead.' At the same time, the 'grave' allows a story teller/creator/listener a mode of subverting the power equations of the material world: the sacred 'grave' of the pious Islamic man negates the power of the British colonial motivated industrialization and scientific innovation, represented by the 'train.' Thus, a 'grave' becomes a mode of absorbing the tensions of the subjects living under colonial rule; it also becomes a site of resistance for a human being seeking justice over his mode of death; the 'grave' assumes anthropomorphic qualities, becomes a witness and articulates the injustice meted out to the dead person.

story is also appears in Kondadeniye Hamuduruwange Viskam. See the References for the complete citation.

${ }^{8}$ Gunasekera (40) in his text Nagenahira Muslimvarunge Sanskruthiya identifies Siyaram as a place where religious leaders who have committed themselves to propagating Islam are buried. 


\section{Power of religion}

Some of the tales directly disseminate the profound respect and veneration of the tale tellers/creators/listeners towards Islam. Six (06) tales draw Islam into their main plots, thus creating a religious presence in relaxed intimate spaces where folktales were obviously narrated. Thus, in Vishmitha Dehemi Minisa (The Miraculous and Pious Man), a man who was ambushed and seriously injured by thieves in a jungle manages to evade imminent attacks from wild animals by chanting religious verses. In Maha Palliye Divuruma (The Oath in the Grand Mosque), an adulterous man who deliberately uttered lies inside a mosque loses his eyesight. A pious man in the tale Aruma Puduma Thel Ulpatha (The Miraculous Oil Spring), grants a poor woman generous quantities of cooking oil, a feat he achieves by pouring a little oil onto his palm. ${ }^{9}$ In Jeevaka Palliya (The Jeewaka Mosque), a man of different faith who harbored intentions of destroying a mosque dies a mysterious death; this same mosque features a Tamarind tree that never grows beyond a particular height and a stone that possesses healing properties. The underlying 'folk idea' in these tales is that Islam offers protection to its followers-and death to those who attempt to negate it; thus, the religion has power over worldly events. The graves of deceased pious persons have power over the living; as for the living, those who adhere to the teachings of the Islam, exert certain powers over their external circumstances.

\section{'Physical strength' and perceived 'threats'}

At least two tales in this collection feature males of extraordinary strength committing incredible deeds. Adam Lebbe, featured in the tale Adam Lebbegae Weerakatha (The Heroic Tales of Adam Lebbe) is capable of outrunning Elephants, bludgeoning a Leopard, and overcoming a Bear with his bare hands. The giant in the tale Muslim Yodhaya (The Muslim Giant) is capable of Herculean tasks like carrying two massive trees on his shoulders a long distance to build a well. His grave is considered a sacred site and is believed to be 60 feet long. The 'folk idea' at play here is the valorizing of masculine physical strength that could transform and manipulate

${ }^{9}$ This motif of creating larger quantities of food from a minuscule food sample is a common motif in the Sinhala folktales collected by Henry Parker. 
the physical world. Since spirituality also achieved the same purpose in the above-discussed tales, one could assume that sheer physical capacity is also considered as a sacred ability-an idea further reinforced by the sacredness granted to the grave in the tale Muslim Yodhaya. The incredible deeds ascribed to these two characters also remind one of the characters from King Dutu Gemunu's army, popularly known as the Dasa Maha Yodhayo (Ten Great Giants). The writer of the Mahavamsa,10VenMahanama, could have exaggerated the strengths of these ten men in order to disseminate the idea of the intensity and the difficulty of the struggle that lay ahead for the hero of the Sinhala race, Dutu Gemunu. And by creating such mighty men he might have offered some kind of 'textual consolation' for his readers in the $5^{\text {th }}$ Century ACE, when the nation faced imminent threats from South India. Similar motivations could have governed the Muslim story tellers/creators as they created stories that narrate the presence-rather than the absence-of males with enormous 'physical strength' in their community. The stories could have been inspired by perceived threats to the Muslim community from outside. In the tale, Sinhala-Muslim Premaya (The Sinhala-Muslim Romance), Sinhala villagers confront a Muslim man who had married a female from their village; in Jeevaka Palliya - already discussed above-a man from a different faith attempted to destroy a mosque. Perhaps such perceived threats from outside might have motivated the creative energies of the story tellers/creators to conceive the idea of the existence of exceptional masculine strength and courage within their community.

\section{Power of the dream}

The story tellers have positioned the 'dream' as a powerful conveyor of crucial information. Thus, in the tale Sagarayak Meda Dutu Sihiniya (A Mid-Sea Dream), a fisherman whose boat had overturned follows the imperatives given in a dream and saves his life. In Jeevaka Palliya, a voice heard in a dream directs a man to build a mosque in his private land. Both these dreams involve a 'voice'-not 'images'-and play into the idea of the absence of images in Islam. These tales are built on the 'folk idea' of the 'dream' as a sacred space where communications could happen

${ }^{10}$ Chapter 13 of the Mahavamsa (Wilhelm Geiger translation) offers descriptions of these warriors 
between the human realm and other 'superior' ones.

\section{The 'Other' as a 'threat'}

The treatment of non-Muslims by the Muslim story tellers offers interesting insights about the 'folk idea/s' created around and inspired by the presence of the 'others' amidst their community. In Sinhala-Muslim Premaya the story tellers experiment with the idea of inter-communal romance between a Muslim male and a Sinhala female. The intensity of that romance is tested when an armed Sinhala mob attempts to abduct the Sinhala female. The issue is settled through negotiations and the marriage stands as it is. The story teller concludes the tale by suggesting the subsequent generations who were a result of that marriage could be seen at present, and that the Muslim identity of such people could be verified by their superior physical attraction (Lassana). The underlying 'folk idea' at play here is that people from the Muslim community are physically attractive. In Jeevaka Palliya, a man from an unidentified faith, who attempted to destroy a newlybuilt mosque, dies of a tragic accident merely 24-hours after his original intention. Here the Muslim story tellers/creators have violently dispatched a man who had harbored destructive ideas against their religion-this act is underpinned by the 'folk idea' that violation of Islam is resisted by forces beyond human comprehension. In the tale Handunkuru Gura (The Incense Stick Ascetic), a Muslim man, who was previously a butcher, finds better means of earning money: he mimics a 'sacred man' by carrying a bunch of incense sticks and walking across the village. His long beard, the time of his sudden appearance (evening) in the village and the presence of the 'incense sticks'-an object used in prayer in both the Buddhist and Hindu places of worship-all help him convince the villagers of his soothsaying ability (penabelima). The gullible villagers believe him and consult him with their mundane worldly issues. He predicts their future, not through psychic means, but by gathering information about his customers through an ingenious mode of spying. He ends up becoming rich. This story suggests the gullibility and credulity of the non-Muslim people who believe in the magical arts. The causal 'folk idea' at play here is that deliberate human interaction with the unseen events of the future and the past (which is what a penabelima offers an interested participant) is a non-event; such beliefs can make one vulnerable to be misled and cheated. 


\section{Conclusions}

Collective thoughts inscribed in these 'folk ideas' could be analyzed to build the possible 'worldview' shared of the Digamadulle Muslim community. The 'world' as perceived by this community consists of two different, yet overlapping spheres of influence-one material and the other spiritual. The material sphere is a space of defects: this space is under 'threat' from outsiders. The perceived 'threats' could be from government authorities, other communities, and misguided elements in a society like thieves. However, these perils are negated to a larger extent by the presence of the spiritual dimension, which is defined by Islam. The Islam-inspired spirituality offers the means to counter such ills and imperfections of the material 'world'; the difficulties of life in the material sphere could be absorbed by the sacred spiritual sphere. These folktales, in essence, are a call for intense spiritual engagements with Islam from the listeners. They valorize the religion as the answer to worldly imperfections and also signal that those who are outside the sphere of Islam will not be offered such sanctuary. The dissemination of such notions of religiosity in common folktales might indicate the importance the religion plays in the lives of the Digamadulle Muslim community on the one hand; on the other hand, such imperatives could also be interpreted as motivated by the fear of the lack of interest in the religion among the younger generation. Either way, these tales narrate the ideas that are intimate to the Muslim community of a specific time/space dimension-and might offer us the means to understand their existential postulates when it comes to living. Here is a community who attempts to/prefers to view the world through the spiritual lenses of Islam and who resist any attempts to disrupt that view. Any engagement with this communitynational or individual-needs to take this concern into account. Perhaps, the following narration from Sinhala-Muslim Premaya, a story that espouses the notion of ethnic blending-narrated by a relatively young Muslim male from Akkaraipattu-might offer some ideas when it comes to post war ethnic integration in Sri Lanka. He narrates the moment of the arrival of a child in the Sinhala-Muslim marriage: "Her parents, meanwhile, heard that their daughter had given birth to her first child. The arrival of the child managed to subdue the anger that the parents have harbored against the couple. They both came to Eragama with gifts to see their grandson." Metaphorically, the 'grandson' in the tale-whose presence negates the notions of aggression and 
fosters peace and harmony-could represent a fresh mode of perceiving, understanding and engaging with the ethnic communities in modern Sri Lanka.

\section{References}

Bronner, Simon J. ed. (2007). The Meaning of Folklore. The Analytical Essays of Allan Dundes. Utah State University Press: Utah.

Bronner, Simon J. Ed. Manly Traditions. (2005) The Folk Roots of American Masculinities. Indiana University Press: Indiana.

Davy, John. (1821). An Account of the Interior of Ceylon and of its Inhabitants with Travels in that Island. TissaraPrakasakayo: Colombo.

De Bussche L, Captain. (1817). Letters of Ceylon; Particularly Relative to the Kingdom of Kandy. Asian Educational Services: New Delhi.

Dundes, A. (2007). The Meaning of Folklore. Utah State University Press: Utah. Gunesekera, Gunasoma.(2003).Digamadulle Muslim JanakathaS. Godage \& Sons: Colombo.

Jordan, Rosan A., \& Susan J. Kalcik. ed. (1995). Women's Folklore, Women's Culture. University of Pennsylvania Press: Pennsylvania.

Man, John. (2011). Genghis Khan. Life, Death and Resurrection. Bantam Books: London.

Nuhman, M.A. (2002). Understanding Sri Lankan Muslim Identity. International Centre for Ethnic Studies: Colombo.

Parker, H. (2010) Village Folk Tales of Ceylon Volume I. TissaraPrakasakayo: Colombo.

Parker, H. (2010) Village Folk Tales of Ceylon Volume II. TissaraPrakasakayo: Colombo.

Parker, H. (2010) Village Folk Tales of Ceylon Volume III. TissaraPrakasakayo:

Colombo. 
Samarasinghe, S.G. (2014). Folklore as a Repository of Traditional Wisdom in Sri Lanka. Quoted from Journal of the Royal Asiatic Society, Colombo VolXLVII. (pg 35-66).

Suriyarachchi, N. (2013). KondadeniyeHamuduruwangeViskam. Sarasavi:Colombo.

Wickramasinghe, Nira. (2002). History Writing: New Trends and Methodologies. International Centre for Ethnic Studies: Colombo.

Wickramasinghe, M. (1948). Landmarks of Sinhalese Literature. Sarasa (Pvt) Ltd: Colombo. 